Pesq. Vet. Bras. 31(2):178-181, fevereiro 2011

\title{
Frequencies of DEA blood types in a purebred canine blood donor population in Porto Alegre, RS, Brazil ${ }^{1}$
}

\author{
Vanessa Sinnott Esteves ${ }^{2}$, Luciana de Almeida Lacerda ${ }^{2}$, Camila Serina \\ Lasta$^{2}$, Viviane Pedralli² and Félix H.D. González ${ }^{2}$
}

\begin{abstract}
Esteves V.S., Lacerda L.A., Lasta C.S., Pedralli V. \& González F.H.D. 2011. Frequencies of DEA blood types in a purebred canine blood donor population in Porto Alegre, RS, Brazil. Pesquisa Veterinária Brasileira 31(2):178-181. Laboratório de Análises Clínicas Veterinárias, Departamento de Patologia Clínica Veterinária, Universidade Federal do Rio Grande do Sul, Av. Bento Gonçalves 9090, Porto Alegre, RS 91540-000, Brazil. E-mail: luciana.lacerda@ufrgs.br

The study of canine immunohematology is very important for veterinary transfusion medicine. The objective of this study was to determine the DEA blood type frequencies in a purebred canine blood donor population from Porto Alegre, RS, Brazil. One hundred clinically healthy purebred dogs were chosen, 20 dogs from each breed (Great Dane, Rottweiler, Golden Retriever, German Shepherd and Argentine Dogo). Blood samples were taken in ACD-A tubes and the MSU hemagglutination tube test (MI, USA) was used to determine the blood types. The studied population presented general frequencies of $61 \%$ for DEA $1.1,22 \%$ for DEA $1.2,7 \%$ for DEA 3, $100 \%$ for DEA $4,9 \%$ for DEA 5 and $16 \%$ for DEA 7. A significant association was found between breeds and certain combinations of blood types in this population. The results are in agreement with the literature since most part of the canine population studied was positive for DEA 1.1, the most antigenic blood type in dogs. Differences were found among the studied breeds and those should be considered when selecting a blood donor. The knowledge of blood types frequencies and their combinations in different canine populations, including different breeds, is important because it shows the particularities of each group, helps to keep a data bank of local frequencies and minimizes the risks of transfusion reactions.
\end{abstract}

INDEX TERMS: Blood typing, DEA blood types, dog erythrocyte antigen (DEA), immunohematology, dogs.

RESUMO.- [Frequências dos tipos sanguíneos do sistema DEA em uma população de cães de raça doadores de sangue em Porto Alegre, RS.] O estudo da imunohematologia canina é muito importante para a medicina veterinária transfusional. $\mathrm{O}$ objetivo deste estudo foi determinar as frequências dos tipos sanguíneos do sistema DEA em uma população de cães de raça que fazem parte de um programa de cães doadores de sangue em Porto Alegre, RS, Brasil. Cem cães saudáveis de raça pura

\footnotetext{
${ }^{1}$ Received on December 29, 2009.

Accepted for publication on January 20, 2011.

2 Laboratório de Análises Clínicas Veterinárias (LACVet), Departamento de Patologia Clínica Veterinária, Universidade Federal do Rio Grande do Sul (UFRGS), Av. Bento Gonçalves 9090, Porto Alegre, RS 91540-000, Brazil. " Corresponding author: luciana.lacerda@ufrgs.br
}

foram selecionados, vinte de cada raça (Dogue Alemão, Rottweiler, Golden Retriever, Pastor Alemão e Dogo Argentino). Amostras de sangue foram coletadas em tubos contendo ACD-A e o teste de hemaglutinação em tubo de ensaio da MSU (MI, EUA) foi utilizado para determinar os tipos sanguíneos. A população estudada apresentou frequências gerais de $61 \%$ para DEA $1.1,22 \%$ para DEA 1.2 , $7 \%$ para DEA $3,100 \%$ para DEA $4,9 \%$ para DEA 5 and $16 \%$ para DEA 7 . Uma associação significativa foi encontrada entre as raças e certas combinações de tipos sanguíneos nesta população. Os resultados estão de acordo com a literatura, visto que a maioria da população canina estudada foi positiva para DEA 1.1, o tipo sanguineo mais antigênico em cães. Foram encontradas diferenças entre as raças estudadas e estas devem ser consideradas na seleção de um doador de sangue. O conhecimento das 
frequências dos tipos sanguíneos e de suas combinações em diferentes populacões caninas, incluindo diferentes raças, é importante, pois demonstra as particularidades de cada grupo, auxilia na manutenção de um banco de dados sobre as frequências locais e minimiza os riscos de reações transfusionais.

TERMOS DE INDEXAÇÃO: Tipagem sanguínea, antígeno eritrocitário canino, imunohematologia, cães.

\section{INTRODUCTION}

The Dog Erythrocyte Antigen (DEA) system is the only blood group classification internationally recognized. The DEA system is composed by 7 canine blood types with typing sera availability for only five of those (DEA 1, DEA 3, DEA 4, DEA 5 and DEA 7) (Hohenhaus 2004, Blais et al. 2007).

The blood groups correspond to several antigens classified as polymorphic, species-specific, and which are present on the surface of erythrocytes and are detected by immune reactions using antibodies (Reid \& Westhoff 2003).

It is important to perform blood typing and crossmatching prior to a blood transfusion to determine the compatibility between the blood donor and the recipient. This approach minimizes the frequency of reactions and their severity (Giger et al. 1995, Melzer et al. 2003, Lucas et al. 2004, Bracker \& Drellich 2005, Tocci \& Ewing 2009).

Over the past few decades, blood transfusions and the study of canine immunohematology have become essential for the treatment of many diseases. Considerable changes like the development of new technologies, the improvement in the understanding of the appropriate use of blood and of its components, and the characterization of the implications of an incompatible transfusion in the animal treatment have occurred (Morrissey \& Cotter 2000, Tocci \& Ewing 2009).

In spite of all these improvements there is still the lack of a clear, simple, and inexpensive typing method for all DEA blood types available (Kessler et al. 2009, Tocci e Ewing 2009). Canine blood typing is based on a hemagglutination reaction in response to polyclonal or monoclonal antibodies, but alloimunization is needed to generate the reagents (Hale 1995, Andrews 2000). At least three methods are commercially available for DEA 1.1 typing and only one for the other types (Giger et al. 2005).

Most research concerning canine blood typing reports the general population frequencies of DEA blood types or just that of DEA 1.1, and few papers mentioned the frequencies of DEA blood types for different breeds and their possible combinations (Table 1). However, some evidences of breed differences have been reported as well as an association of blood types with immune-mediated diseases (Ejima et al. 1986, Symons \& Bell 1991, Van der Merwe et al. 2002, Novais 2003, Miller et al. 2004, Gracner et al. 2007). The purpose of this study was to determine the frequencies of DEA blood types and their combinations in a population of purebred canine blood donors in Porto Alegre, RS, Brazil.

\section{MATERIALS AND METHODS}

Animals and sample procedures. One hundred clinically healthy dogs from five breeds (Golden Retriever, German Shepherd, Rottweiler, Great Dane and Dogo Argentino, 20 from each breed) with ages between one and eight years were chosen, without distinction of gender. All dogs are participants in a canine blood donor program. No brothers or sisters of the same litter were used in this study. Blood samples $(8.5 \mathrm{~mL})$ were taken from cephalic or lateral saphenous veins in Acid Citrate Dextrose, solution A (ACD-A) (BD-Brasil, São Paulo, Brazil) tubes for blood typing.

Blood typing. All the ACD-A blood samples were centrifuged, the RBCs were washed three times using PBS solution (phosphate buffered saline, $\mathrm{pH} 7.2$ ) and a 5\% RBC suspension was prepared. The typing reagents (polyclonal serum produced in dogs by alloimmunization), standardized by the Michigan State University (MSU): Immunohematology \& Serology Laboratory (MI, USA) were used and the results were interpreted according to the manufacturer's instructions and described by other authors. The addition of canine polyclonal Coomb's (goat IgG anti-canine IgG, IgM, C3) reagent (VMRD Inc., Washington, USA) was used to improve reactions with DEA 1.X and DEA 1.1 (Novais 2003, Giger et al. 2005).

Statistical analysis. All data were analyzed using SPSS 13.0 for Windows (SPSS Inc., Chicago, Illinois, USA). Frequencies of DEA blood types isolated and combinations were compared between breeds using the Pearson Chi-square test and the Fisher's exact test $(P<0.001)$.

Table 1. Frequencies of canine blood types in different studies

\begin{tabular}{cccccccccc}
\hline$N$ & \multicolumn{7}{c}{ General frequencies of DEA blood types (\%) } & Countries \\
\cline { 2 - 7 } & $1.1(\mathrm{~A} 1)$ & $1.2(\mathrm{~A} 2)$ & $3(\mathrm{~B})$ & $4(\mathrm{C})$ & $5(\mathrm{D})$ & $6(\mathrm{~F})$ & $7(\mathrm{Tr})$ & $8(\mathrm{He})$ & \\
\hline$*$ & 44.6 & 19.0 & 5.5 & 98.4 & 22.3 & 99.4 & - & - & US (Swisher \& Young 1961) \\
$*$ & 44 & 22 & 24 & - & 10 & 50 & - & - & Japan (Ejima et al. 1986) \\
968 & 42.3 & 5.8 & - & - & - & - & - & - & Australia (Symons \& Bell 1991) \\
233 & 47 & - & - & - & - & - & - & - & South Africa (Van Der Merwe et al. 2002) \\
150 & 57 & 41 & 13 & 93 & 7 & - & 11 & - & Brazil (Novais 2003) \\
23 & 39 & 17.4 & 13 & 91.3 & 22 & - & - & - & US (Giger et al. 2005) \\
300 & 53.35 & - & - & - & - & - & 39.33 & - & Brazil (Souza 2005) \\
30 & 66.7 & - & - & - & - & - & - & - & Croatia (Gracner et al. 2007) \\
118 & 55.9 & - & - & - & - & - & - & - & US (Lucidi 2007) \\
9,570 & 42 & 12 & 7 & 98 & 11 & - & 20 & - & US (Hale et al. 2008) \\
30 & 90 & 10 & & & & & & Croatia (Zubcic et al. 2008)
\end{tabular}

$\overline{\mathrm{a}} \mathrm{N}=$ Number of dogs tested; ${ }^{*}=$ the number of dogs tested are different for each blood type. 


\section{RESULTS AND DISCUSSION}

Associations between blood types and each breed were found in this study (Table 2 and 3). No sample showed autoagglutination or hemolysis.

The results of the present study were similar to other works; however, the frequencies of some blood types and their combinations were very different among breeds. The authors are aware that geographical variations in the frequencies of blood types may occur according to the genetic origin of the animals, due to the international travel and breeding. Most part of the dogs used in this study was from breeding kennels/programmes, and there is some shared parentage.

Fourteen percent of all tested dogs were positive only for DEA 4 ("Universal" type). German Shepherd and Argentine Dogo showed an incidence of the "universal" type greater than the average population frequency, as also demonstrated by other authors. Forty-seven percent of all tested dogs were positive only for DEA 1.1 and 4. Rottweiler, Great Dane and Golden Retriever demonstrated an incidence of this combination greater than the average population frequency, which agrees with other studies (Van der Merwe et al. 2002, Souza 2005, Hale et al. 2008).

Table 2. Frequencies of isolated DEA ${ }^{a}$ blood types

\begin{tabular}{|c|c|c|c|c|c|c|c|c|}
\hline \multirow[t]{2}{*}{ Breed } & \multicolumn{2}{|c|}{$\mathrm{N}$} & \multicolumn{6}{|c|}{ DEA blood types } \\
\hline & Male & Female & 1.1 & 1.2 & 3 & 4 & 5 & 7 \\
\hline German Shepherd & 9 & 11 & 10 & $50 *$ & 15 & 100 & $25^{*}$ & 30 \\
\hline Rottweiler & 8 & 12 & $100 *$ & 0 & 0 & 100 & 0 & 15 \\
\hline Great Dane & 7 & 13 & $95^{*}$ & 0 & 20 & 100 & 5 & 15 \\
\hline Golden Retriever & 8 & 12 & $95^{*}$ & 0 & 10 & 100 & 20 & 25 \\
\hline Argentine Dogo & 6 & 14 & 5 & $60^{*}$ & 0 & 100 & 0 & 0 ** \\
\hline General frequency & 38 & 62 & 61 & 22 & 9 & 100 & 10 & 17 \\
\hline
\end{tabular}

a DEA = Dog erythrocyte antigen; *significant positive association between isolated blood types and certain breeds $(\mathrm{P}<0.001)$; ${ }^{* *}$ significant negative association between DEA 7 and Argentine Dogo.

Table 3. Frequencies of $D E A^{a}$ blood types combinations

\begin{tabular}{lccccccc}
\hline \multicolumn{1}{c}{ Blood type combinations } & \multicolumn{4}{c}{$\begin{array}{c}\text { Frequency } \\
\text { per breed }(\%)\end{array}$} & $\begin{array}{c}\text { Total } \\
(\%)\end{array}$ \\
\cline { 2 - 6 } & $\begin{array}{l}\text { GSD } \\
\text { RW }\end{array}$ & GD & GR & AD & \\
\hline DEA1.1, DEA3, DEA4 & 0 & 0 & 5 & 5 & 0 & 2 \\
DEA1.1, DEA3, DEA4, DEA5, DEA7 & 0 & 0 & 5 & 5 & 0 & 2 \\
DEA1.1, DEA3, DEA4, DEA7 & 0 & 0 & 10 & 0 & 0 & 2 \\
DEA1.1, DEA4 & 5 & $85^{*}$ & $75^{*}$ & $65^{*}$ & 5 & 47 \\
DEA1.1, DEA4, DEA5, DEA7 & 0 & 0 & 0 & 15 & 0 & 3 \\
DEA1.1, DEA4, DEA7 & 5 & 15 & 0 & 5 & 0 & 5 \\
DEA1.2, DEA3, DEA4, DEA5, DEA7 & 10 & 0 & 0 & 0 & 0 & 2 \\
DEA1.2, DEA3, DEA4, DEA7 & 5 & 0 & 0 & 0 & 0 & 1 \\
DEA1.2, DEA4 & $25^{*}$ & 0 & 0 & 0 & $60^{*}$ & 17 \\
DEA1.2, DEA4, DEA5 & 5 & 0 & 0 & 0 & 0 & 1 \\
DEA1.2, DEA4, DEA7 & 5 & 0 & 0 & 0 & 0 & 1 \\
DEA4 & $25^{*}$ & 0 & 5 & 5 & $35^{*}$ & 14 \\
DEA4, DEA5 & 10 & 0 & 0 & 0 & 0 & 2 \\
DEA4, DEA7 & 5 & 0 & 0 & 0 & 0 & 1 \\
Total & 100 & 100 & 100 & 100 & 100 & 100
\end{tabular}

a DEA = Dog erythrocyte antigen; GSD = German Shepherd; RW = Rottweiler; GD = Great Dane; GR = Golden Retriever; $A D=$ Argentine Dogo; * significant positive association between combinations of blood types and certain breeds $(\mathrm{P}<0.001)$.
The Argentine Dogo (also known as Dogo Argentino or Argentinian Mastiff) is a large strong breed relatively prevalent in the south of Brazil. The good temperament shown by those animals during the blood sampling and blood donation is remarkable and the high frequency of DEA 1.1 negative dogs is another good advantage of this breed as blood donors.

The German Shepherd is another breed that was found to have a high frequency of DEA 1.1 negative dogs in our study, but a study in São Paulo (Brazil) showed 64\% DEA 1.1 positive dogs, and the most frequent combination in that study was DEA 1.1, 4 (50\%) (Novais 2003). This difference could be attributed to the genetic origin of the animals.

Blood types could be also related to some diseases. A study reported that the absence of DEA 7 was associated with an increased risk of immune-mediated hemolytic anemia (IMHA) in Cocker Spaniels. In the present study a significant negative association was found between DEA 7 and Argentine Dogos but no case report has been published concerning IMHA involving this breed (Miller et al. 2004).

The use of canine females with prior history of pregnancy in blood donor programs has always raised controversy due to the possibility of sensitization to RBC antigens and consequent neonatal isoerythrolysis. According to a recent study, the prevalence of naturally occurring alloantibodies was similar in nulliparous dogs compared with dogs with a prior history of pregnancy. The same study also revealed that there is no need to exclude previously pregnant dogs from blood donor programs (Blais et al. 2009). Nevertheless, care must be taken during pretransfusion procedures in canine females, since neonatal isoerythrolysis occurs in DEA 1-positive pups when DEA 1-negative bitches immunized with IV injections of DEA 1-positive RBC and mated with DEA 1-positive sires. The fact was not observed on DEA 4-positive puppies born from DEA 4-negative bitches immunized against DEA 4 by blood transfusions (Young et al. 1951, Swisher \& Young 1961).

Besides the high frequency of DEA 1.1 and other blood types in some breeds, the authors of this study do not have the intention of discouraging the use of those animals as blood donors when there is a positive DEA 1.1 recipient.

In conclusion, this study demonstrate general frequencies of DEA blood types of $61 \%$ for DEA $1.1,22 \%$ for DEA $1.2,7 \%$ for DEA 3, $100 \%$ for DEA 4, 9\% for DEA 5 and $16 \%$ for DEA 7. A significant association was found between breeds and certain combinations of blood types in this population. German Shepherd and Dogo Argentino had significant positive association with DEA 1.2 and 4 , and the other breeds with DEA 1.1 and 4 . The authors believe that the knowledge of the frequencies of blood types and their combinations in dog populations should be considered when selecting a blood donor to avoid sensitization to antigens that could possibly cause transfusion reactions. More studies are needed in a larger scale and for each Brazilian region, considering the small size of the present survey and the fact that Brazil has at least 31 million dogs (PhillipsDonaldson 2008). 
Acknowledgments. To the owners and breeders that allowed their dogs to participate in this study and in the canine blood donor program of our Faculty, and BD-Brasil/ Pre-analytical systems for the products used in this study.

\section{REFERENCES}

Andrews G.A. 2000. Red blood cell antigens and blood groups in the dog and cat, p.767-7737 In: Feldman B.F., Zinkl J.G. \& Jain N.C. (Eds), Schalm's Veterinary Hematology. $5^{\text {th }}$ ed. Lippincott Williams and Wilkins, Philadelphia. 1344p.

Blais M.C., Berman L., Oakley D.A. \& Giger U. 2007. Canine Dal Blood Type: A red cell antigen lacking in some Dalmatians. J. Vet. Intern. Med. 21:281-286.

Blais M.C., Rozanski E.A., Hale A.S., Shaw S.P. \& Cotter S.M. 2009. Lack of evidence of pregnancy-induced alloantibodies in dogs. J. Vet. Intern. Med. 23:462-465.

Bracker K. \& Drellich S. 2005. Transfusion reactions. Comp. Cont. Educ. Pract. 7:500-511.

Ejima H., Kurokawa K. \& Ikemoto S. 1986. Phenotype and gene frequencies of red blood cell groups in dogs of various breeds reared in Japan. Jpn. J. Vet. Sci. 48:3633-68.

Giger U., Gelens C.J., Callan M.B. \& Oakley D.A. 1995. An acute hemolytic transfusion reaction caused by dog erythrocyte antigen 1.1 incompatibility in a previously sensitized dog. J. Am. Vet. Med. Assoc. 206:1358-1362.

Giger U., Stieger K. \& Palos H. 2005. Comparison of various canine blood-typing methods. Am. J. Vet. Res. 66(8):1386-1392.

Gracner D., Bedrica L., Labura C., Maticic D., Gracner G.G. \& Samardzija M. 2007. Blood groups and haematology in Istrian pointers. Vet. Arhiv 77:95-102.

Hale A.S. 1995. Canine blood groups and their importance in veterinary transfusion medicine. Vet. Clin. North Am., Small. Anim. Pract. 25(6):1323-1332.

Hale A.S., Werfelmann J., Lemmons M., Smiler B. \& Gerlach J. 2008. An evaluation of 9,570 dogs by breed and dog erythrocyte antigen typing. Research Abstract Program of the $26^{\text {th }}$ Annual ACVIM Forum 1:740. (Abstract)

Hohenhaus A.E. 2004. Importance of blood groups and blood group antibodies in companion animals. Transfus. Med. Rev. 18(2):117126.

Kessler R.J., Reese J., Chang D., Hale A. \& Giger U. 2009. Extended canine blood typing by Gel Column Technique. Research Abstract Program of the 2009 ACVIM Forum and Canadian Veterinary Medical Association Convention, Vol.1, p.694. (Abstract)

Lucas R.L., Lentz K.D. \& Hale A.S. 2004. Collection and preparation of blood products. Clin. Tech. Small Anim. Pract. 19:55-62.

Lucidi C.A. 2007. Pesquisa do antígeno eritrocitário canino $1.1 \mathrm{em}$ plaquetas de cão. MSc Dissertation, Faculdade de Medicina Veterinária e Zootecnia, Universidade Estadual Paulista, Botucatu, SP. 91p.

Melzer K.J., Wardrop K.J., Hale A.S. \& Wong V.M. 2003. A hemolytic transfusion reaction due to DEA 4 alloantibodies in a dog. J. Vet. Intern. Med. 17(6):931-933.

Miller S.A., Hohenhaus A.E. \& Hale A.S. 2004. Case-control study of blood type, breed, sex, and bacteremia in dogs with immune-mediated hemolytic anemia. J. Am. Vet. Med. Assoc. 224(2):232-235.

Morrissey P. \& Cotter S. 2000. I need blood, stat: Canine transfusion medicine. Vet. Tech. 21(5):273-278.

Novais A.A. 2003. Prevalência dos antígenos eritrocitários caninos em cães domésticos (Canis familiaris) e investigação dos parâmetros hematológicos e da ocorrência de antígenos eritrocitários em lobos-guará (Chrysocyon brachyurus) e cachorros-do-mato (Cerdocyon thous). Tese de Doutorado, Faculdade de Ciências Agrárias e Veterinárias, Universidade Estadual Paulista, Jaboticabal, SP. 50p.

Phillips-Donaldson D. 2008. Global growth continues: Highlights of key growth regions and countries show why the global petfood market is booming. Petfood Industry 5:20-21.

Reid M.E. \& Westhoff C.M. 2003. Membrane blood group antigens and antibodies, p.11-19. In: Hillyer C.D., Silberstein L.E., Ness P.M. \& Anderson K.C. (Eds), Blood Banking and Transfusion Medicine: Basic principles and practice. Churchill Livingstone, Philadelphia. 624p.

Souza S.L. 2005. Estudo da freqüência dos grupos sanguíneos DEA 1 e DEA 7 em cães de diferentes raças como subsídio à implantação de banco de sangue canino na Faculdade de Medicina Veterinária e Zootecnia da Universidade de São Paulo. Dissertação de Mestrado, Faculdade de Medicina Veterinária e Zootecnia, USP, São Paulo. $56 \mathrm{p}$.

Swisher S.N. \& Young L.E. 1961. The blood grouping systems of dogs. Physiol. Rev. 41:495-520.

Symons M. \& Bell K. 1991. Expansion of the canine A blood group system. Anim. Genet. 22(3):227-235.

Tocci L.J. \& Ewing P.J. 2009. Increasing patient safety in veterinary transfusion medicine: An overview of pretransfusion testing. J. Vet. Emerg. Crit. Care 19(1):66-73.

Van Der Merwe L.L., Jacobson L.S. \& Pretorius G.J. 2002. The breed prevalence of dog erythrocyte antigen 1.1 in the Onderstepoort area of South Africa and its significance in selection of canine blood donors. J. S. Afr. Vet. Assoc. 73(2):53-56.

Young L.E., Christian R.M., Ervin D.M., Davis R.W., O'brien W.A., Swisher S.N. \& Yuile C.L. 1951. Hemolytic disease in newborn dogs. Blood 6(4):291-313.

Zubcic D., Bedrica L., Gracner D., Harapin I., Fury M. \& Jeremic J. 2008. Blood groups, haematology and clinicochemical indicators in indigenous breeds of dog. I. Croatian sheepdogs. Vet. Arhiv 78(2):141147. 